\title{
BASIC PRINCIPLES OF PRODUCTION-AND-TECHNICAL POTENTIAL CAPACITY FORMATION IN THE CONSTRUCTION INDUSTRY OF A REGION
}

\author{
Natalia Vladimirovna Bredikhina ${ }^{1^{*}}$ \\ ${ }^{1}$ Southwest State University, Kursk, Russia
}

The paper discusses a structural model of potential capabilities and development patterns of a regional production-and-technical potential capacity of construction industry organizations. The model utilizes quantitative assessment of a maximal possible efficiency of resource utilization by a construction organization.

Key words: Construction activity, Investment and construction system, Organization's resources, Production-and-technical potential capacity

One of the biggest challenges that construction industry agents have to face is to assess their initial state in terms of development possibilities. The development potential is determined by qualitative and quantitative characteristics of available resources together with their ability for a flexible response to market changes, which in the final count specifies the organization's strategies and defines its policy, commercial goals and objectives, activity programs and the approaches to their implementation.

The scarcity of resources makes the task even more complicated; hence the primary attention should be paid to qualitative and quantitative measurements of the available resources and the production and technical capacities of an organization. The accuracy of such measurements is essentially important for taking appropriate decisions that will be able to gain serious advantages due to timely relocating of production facilities, material, labor and innovative resources to the production of construction goods and services that can enjoy the highest demand in the current market situation [01]. In its turn it involves certain changes in the organization's policies and its relationships with perspective investors, customers, suppliers, contractors and subcontractors.

In market economic conditions total potential resources of an organization are built up under the influence of several factors such as the development of market relationships, emerging and developing competition, acceleration of scientific and engineering progress, increasing role of information technologies, efficiency of labor force use, better production organization and management, maximal utilization of production capacities, cost-effective consumption of material and energy resources, workforce education, training and personal involvement and application of market research [02]. All these factors have rather selective than aggregate influence and act on different resource components with different force. Thus final potential resources of an organization are formed as an integrated sum-total of all production and technical abilities of each resource component.
In this way the total potential resources of an organization can be viewed as a sum-total of the organization's possibilities to produce goods and services, which presupposes maximally effective utilization of all available resources needed to manufacture the demanded construction items by implementing up-to-date technologies, best production practices, advanced industrial engineering with ensured occupational safety and environment protection. Hence production and technical potential resources are the main factor that determines the scope of construction goods (services) and their supplying conditions [03, 04].

Production and technical potential is a general characteristic of manufacturing and engineering capacities of all main production elements that make a holistic system that is able to be adapted to market conditions, i.e. all labor, material, energy and IT resources are to be considered as continuously interacting elements at a certain time period. As a construction organization is a structured system with its resource capacities having a consistent nature, each resource element should be considered as a subsystem.

Thus the production and technical potential resource can be described as a summary quantitative assessment of the maximal possible efficiency with which a construction organization uses its resources under the conditions when the production of construction goods is rationally organized and all economic agents who are investing into construction are interacting in the most effective way [05]. If we define production and technical potential resources as a unified system with all its structural elements functioning to meet a single goal, we should focus on the structural aspect of this problem and analyze the development, interaction and relationships of its main elements, or individual resources.

Considering that production and technical potential resources have a very complex nature with multiple aspects, its constituting elements should be assessed by applying only comparable unified indicators. 
In the final result it will allow us to calculate a single integrated index of the production and technical capability of an organization [06].

Having studied modern market economy situation we have found that investment and construction activities of regional authorities, that are responsible for the administration of investment and construction network of the region, are largely dependent on the choice of the most efficient mechanism to be used to organize and manage the construction and manufacturing activities of both construction organizations and manufacturers of construction goods so that to enable further expansion of the local construction goods market taking into account the current state of urban renovation and refurbishment activities.

Main production and investment goal setting and their implementation need to have open possibilities for the growth of construction and erection orders, as well as sufficient resource capacities of construction industries. In the general case the resource capacity of any production system is an assessment of the potential ability of this enterprise to produce specific goods with the required quality grade (expressed both in natural and cost values) during a specified time period (usually during a planned year), i.e. resource capacity is an integral estimation of the efficiency (capacity) of a constriction industry enterprise [07].

However from the perspective of a local investment and construction group the resource capacity of a construction integrated industrial system (in our understanding this is a construction organization and a construction industry) also characterizes the acceptable level of its investment resources and its possibilities to construct (renovate) residential buildings [08].

We see the regional production potential capacity as an actual volume of the production that can be produced with complete utilization of all available investment resources in the given region (locality); it is also all actually available and likely production capabilities, the availability of production factors and necessary key resources. Technical potential is understood as a sum-total of all economic agent's technical and technological resources that can be used to conducts economic activities related either with the production of construction goods (items) or delivering services to meet the public demand and thus to stimulate the growth of consumption and production. We think that these potential possibilities should be treated as one aggregated production-and-technical potential capability that is an ultimate characteristic of the potential capacity of an enterprise. This characteristics integrates internal indicators of the productive capacity of a system and its volumetric potential capacity with production-and-economic indicators of the organization's current position on the market of construction goods and services. The most critical stage in the modeling of the production-and-technical potential capacity of a region is a systematic description of its functioning and development processes.
This stage should include the following steps:

1. to define the goals and objectives of the regional potential functional capacity;

2. to define the criteria the regional potential functional capacity assessment;

3. to determine the place of the regional potential capacities in the higher system, to describe the environment, interaction mechanisms and forms;

4. to describe inner structure of the regional potential capacity and the functions of the constituting elements;

5. to identify information relations between the external environment and the regional potential capacities, as well as the relationships between the subsystems and elements that form its internal structure;

6. to outline a concept of the regional potential capacity functioning and development.

As we have already marked, in order to describe a regional potential capacity as a system, it is necessary to identify the goals of its functioning.

Complex social and economic systems, and a region is certainly a complex system, are characterized by multiple goals and objectives. Such goals may include:

- system stabilization and sustainable development of the region;

- ensured employment of economically active population and absence of social strain;

- ensured stable financial situation in regional economy;

- rehabilitation of environment in order to guarantee environmental safety of daily life activities;

- ensured conditions for self-regeneration of the regional potential capacities.

There are two approaches to the selection of the criteria to be applied to assess regional potential capacity. The amount of a regional production-and-technical potential capacities can be measured by its structural state and integrated reliability index. This approach is based on the assumption about the commensurability of the functional abilities of the whole system and its structural parameters. Actually these possibilities notably depend on the production conditions and general economic factors, including intersectoral links [09].

The second approach is focused on the regional potential capacity performance indicators. The efficiency of its functioning can be measured either by one integrated index, or by several individual indices, each of which shows the achievement of a certain functional goal. However in this case we have to face the multicriteriality problem that requires reducing all criteria to one. So we suggest that one main criterion should be used. As for the choice of a specific assessment criteria, there is no single agreed opinion [10,11]. Considering our previous findings we think that one of the following indices can be used: 
- gross regional product (GRP);

- net regional product (NRP);

- national income (NI);

- personal income (PI);

- incomes of local authorities (LAI).

To a certain extent the above indicators represent the target interests of different groups of regional subordinated entities.

\section{REFERENCES}

1. Сервейинг: организация, экспертиза, управление. Часть первая. Организационнотехнологический модуль системы сервейинга / под. общ. ред. П.Г.Грабового. М.: Изд-во «АСВ», ИИА «Просветитель», 2015. 560 с.

2. Саати Т., Кернс К. Аналитическое планирование. Организация систем / Т.Саати, К.Кернс. М.: Радио и связь, 1991. 224 с.

3. Олдак П.Г. Формирование современного экономического мышления / П.Г.Олдак. М.: Наука, 1989. $160 \mathrm{c}$.

4. Волкова С.Н. Определение временных границ новых распределений экономических законов. / С.Н. Волкова, Ю.И. Майоров, А.В. Шлеенко // Экономический анализ: теория и практика. - М. 2009, октябрь. -№ 28 (157). - С. 2 - 4.

5. Бредихин В.В., Шлеенко А.В., Бредихина Н.В. Развитие производственно-технического потенциала строительной отрасли региона / В.В.Бредихин, А.В.Шлеенко, Н.В.Бредихина. Курск: Изд-во Юго-Зап. гос. ун-та, 2016. 118 с.
6. Бредихин В.В. Проблемы управления производственно-техническим потенциалом территориально-инвестиционного строительного комплекса (ТИСК) в условиях конкурентной среды // Под ред. Грабовый П.Г., Капырин Д.А. Недвижимость: экономика, управление. 2012. № 1. С. 47-51.

7. Организация, планирование и управление строительством / под общ. ред. П.Г.Грабового и А.И.Солунского. М.: Проспект, 2013. 528 с.

8. Бредихин В.В. Приоритетные мероприятия В области стимулирования предложений по формированию рынка муниципального жилья с учетом региональных особенностей // Известия Юго-Западного государственного университета. Серия: Техника и технологии. 2013. № 2. С. 082090.

9. Бредихин В.В. Сравнительный анализ интеграционных структур управления и критерии обоснования их оптимальности // Известия Юго-Западного государственного университета. Серия: Техника и технологии. 2012. № 2-3. С. 164-170.

10. Саати Т. Л. Принятие решений при зависимостях и обратных связях: Аналитические сети / Т.Л.Саати. М.: Изд-во ЛКИ, 2008. 360 с.

11. Саати Т. Л. Целочисленные методы оптимизации и связанные с ними экстремальные проблемы / Т.Л.Саати. М.: Мир, 1973. 302 с. 